\title{
Formation of normative-methodical maintenance of quality and safety of campsites
}

\author{
Daniil A. Cherepanov ${ }^{1, *}$, Aleksandr S. Ermakov ${ }^{1}$, Marina $\mathrm{R}$. Gozalova ${ }^{2}$, Aleksandr Ya. \\ Korolchenko ${ }^{1}$ \\ ${ }^{1}$ Moscow State University of Civil Engineering, 26, Yaroslavskoye Shosse, 129337 Moscow, Russia \\ ${ }^{2}$ Russian State University of Tourism and Service, Moscow, Russian Federation
}

\begin{abstract}
Organization of campsites construction for auto tourists in Russia is an effective means of ensuring their rest and sleep during travel. Formation of normative and methodological support of campsites fire safety should take into account not only security, but also meet consumers' motivation to visit them. The authors examine conditions and requirements for the infrastructure of campsites and their localization, as well as methods of fire risk assessment in camping. They propose camping localization techniques and expert evaluation of fire risk in them.

Key words: construction of the structure, localization, security, camping, normative and methodological support.
\end{abstract}

\section{Introduction}

Constructions easily erected areas for recreation, guest services and cultural, sports, recreational activities, created with minimal anthropogenic influence on the territory and fire risk, are particularly in demand as an effective and economical way of seasonal residence $[1,12]$.

\section{A review of the literature}

Also this is the fulfillment of the Decree of the Russian Government dated August 02, 2011 No. 644 (edition date is February 18, 2014) by the Federal target program "Development of domestic and inbound tourism in the Russian Federation (2011-2018)" through the creation of car-clusters with camping. Improving the construction quality of campsites and their safety is the harmonization of systems of technical regulation of Russia and Europe and their regulatory and methodological support. The most important in ensuring quality and safety is to prevent fires in the campsites as the area has the places with open flame (barbecue, bonfire, etc.), different infrastructure options with external and internal threats, as well as with a significant influence on the choice of the location and infrastructure of the its visitors' motivation. Analysis of the causes of fires in the camping shows the cases of death and the victims among the visitors [4]. Choosing the placement of the campsite construction, it's also important to ensure not only safe $[1,2]$ and comfortable accomodation

* Corresponding author: Supfear@yandex.ru 
on this site, but the opportunity to visit as many tourist attractions of travel destination in accordance with tourists' motivations and needs. The absence of the normative-methodical maintenance of campsites fire safety with different options for their functionality and composition of infrastructure in the special conditions of natural and engineering communications of their placement requires the normative and methodological support development of their fire safety. Campsites, providing high-quality fire-protected operations and safe people evacuation, have a real reduction of material damage in case of fires.

\section{Methodology}

They often use systematic analysis, mathematical modeling, and calculations of fire risks, experimental analysis and testing of camping facilities for research.

\section{Results}

Classification of camping, the level of infrastructure equipment, quantitative scale, location, distance from urban settlements, they are a number of factors influencing fire safety of camping because, in the case of fire in one of the buildings or on one of the camping sites, security of people and property is a really difficult problem $[10,11]$. Each characteristic of the camping [8] has its important role in determining aggregate measures of its fire security.

The specific features of the security, and in particular, the camping fire danger in Russia are determined with significant climatic differences on the territory of the country and the fillings of attractions that motivate consumers; features of the structure and composition of the infrastructure [5, 13], which provide various service functions (accommodation, security, rest, sleep, food, entertainment, etc.); area sites with different threats and their diversity and the availability of means for their prevention and use in the system of fireprotection; organization of the territory, functionally performing the services in accordance with the consumer motivation, not always determined with manufacturing sequence and seasonality capacity and temporary accommodation without creating stationary building structures for the individual species [9].

The system security model of campsites constructions requires the creation of normative-methodical documentation, taking into account the accessibility comfort and stay comfort in accordance with their motivation, as well as all possible threats both external and internal threats, their prevention, protection, alarm systems, warning and evacuation for the purpose of preservation of people's life and health, property, infrastructure and environment.

Classification of campsites in the 5-star principle allows taking into account the variety of campsites (their infrastructure, scale, location, purpose and other features) in fire safety: the higher class of camping has the more types of structures and communications. The most rational measure for Russia to create seasonal campsites is the use of mobile homes $[5,6]$, which are not only able to adapt to changing conditions, preserving the environment [7] of the location and appearance parameters, but also to evacuate easily in emergencies.

The calculations of the structures of the camping, which established their energy load, were carried out to study the level of threats (Fig. 1).

To diagnose security threats in camping, in particular their identification and the assessment of their probability and their consequences, there were compiled diagnostic papers. Diagnostic paper no. 1 depending on the camping location includes information about signs of a threat: external security threats for the platform camping; internal security threats on the camping area; internal security threats in the camping operation. Diagnostic 
paper no. 2 takes into account the category of risks of threats consequences to people's health and life and security of their property and camping.

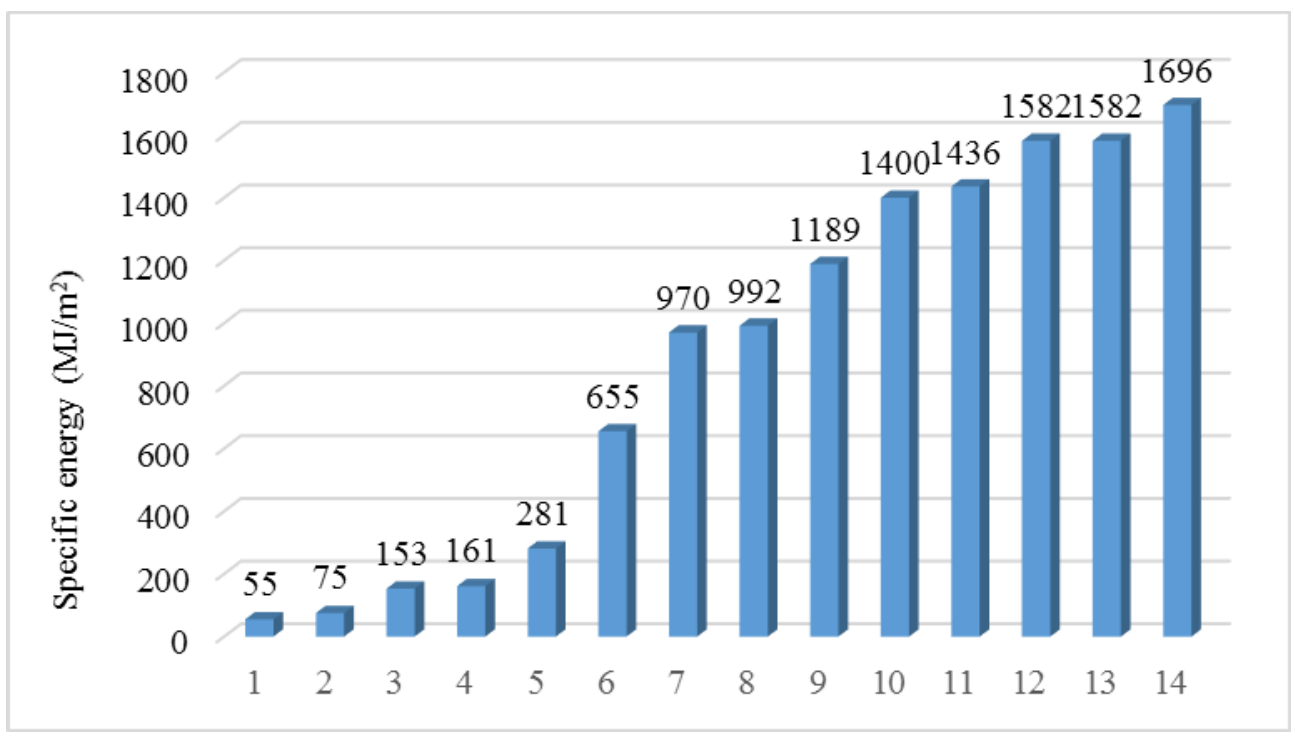

Fig. 1. Comparative analysis of the camping structures on the energy loading: 1 - Two-seat tent (with internal fire load); 2 - Modular shower for 6 people; 3 - Barbecue under a shed with furniture; 4 Four-seat tent (on the pallet with fire load)); 5 - Modular toilet for 6 people; 6 - Trailer-transformer; 7 - Trailer for 2-4 berthes; 8 - Wooden bungalow; 9 - Middle class car on the Parking; 10 - Security post; 11 - Caravan; 12 - Modular shower; 13 - Modular toilet; 14 - Administrative building of III-IV degree of fire resistance.

The most vulnerable structure in the campsite is the tourist tent that determines the need to study fire safety of the tent materials and methods to ensure its fire safety. According to the results of experimental studies of the tent materials there was installed (Fig.2):

reduced flammability due to the use of flame retardant treatment on cotton tent fabrics (the material is not ignited, but get only the charred edges); the effect of the transmittance of the heat flux $T$ through the tent fabric, applying reflective paint, which in comparison with fabric without reflective paint show a decrease for cotton fabric at a distance of $200 \mathrm{~mm}$ from $3.01 \pm 0.25 \mathrm{kV} / \mathrm{m} 2$ to $2.54 \pm 0.23 \mathrm{kV} / \mathrm{m} 2$, and at a distance of $300 \mathrm{~mm}$ from 1.21 $\mathrm{kW} / \mathrm{m} 2 \pm$ of 0.18 to $1.15 \pm 0,17 \mathrm{~kW} / \mathrm{m} 2$; applying a luminous pigment shows the reduction at a distance of $200 \mathrm{~mm}$ from $3.01 \pm 0.25 \mathrm{kV} / \mathrm{m} 2$ to $2.49 \pm 0,2 \mathrm{~kW} / \mathrm{m} 2$, and at a distance of 300 $\mathrm{mm}$ from $1,21 \pm 0,18 \mathrm{~kW} / \mathrm{m} 2$ to $1.09 \pm 0,15 \mathrm{~kW} / \mathrm{m} 2$. The polyester fabric with reflective paint shows the reduction for a distance of $200 \mathrm{~mm}$ from $3.2 \pm 0.3 \mathrm{kV} / \mathrm{m} 2$ to $2.82 \pm 0,25 \mathrm{~kW} / \mathrm{m} 2$ and at a distance of $300 \mathrm{~mm}$ from $1.27 \mathrm{~mm} \pm 0,19 \mathrm{~kW} / \mathrm{m} 2$ to $1.22 \pm 0,2 \mathrm{~kW} / \mathrm{m} 2$; applying a luminous pigment shows the reduction at a distance of $200 \mathrm{~mm}$ from $3.2 \pm 0.3 \mathrm{kV} / \mathrm{m} 2$ to $2.47 \pm 0,22 \mathrm{~kW} / \mathrm{m} 2$, and at distances from $300 \mathrm{~mm}$ to $1.27 \pm 0,19 \mathrm{~kW} / \mathrm{m} 2$ to $1.15 \pm 0,12$ $\mathrm{kW} / \mathrm{m} 2$.

Maximum of fire prevention is achieved through the rational camping localization [3, 5] when the target function will be:

$$
D=\bigcap_{l=1}^{E} t_{1} ; t_{1} \in M^{T} \text { when }\left(\mathrm{A}_{l} \cdot K_{l} \cdot B_{l}\right) \rightarrow \max
$$

where $D$ is rational $E$ quantity of camping localizations in the examined destination $M^{T}$ taking into account the comfort and fire safety, $l=1 \ldots E, t_{l}$ are the coordinates of $l$ the rational point of camping localization in the selected space region, $A_{l}$ are attractions for $l$ 
rational point of camping localization, $B_{l}$ is evaluation of fire safety for $l$ rational point of camping localization, $K_{l}$ is the assessment of comfortable localization and functioning for $l$ rational point of camping localization.
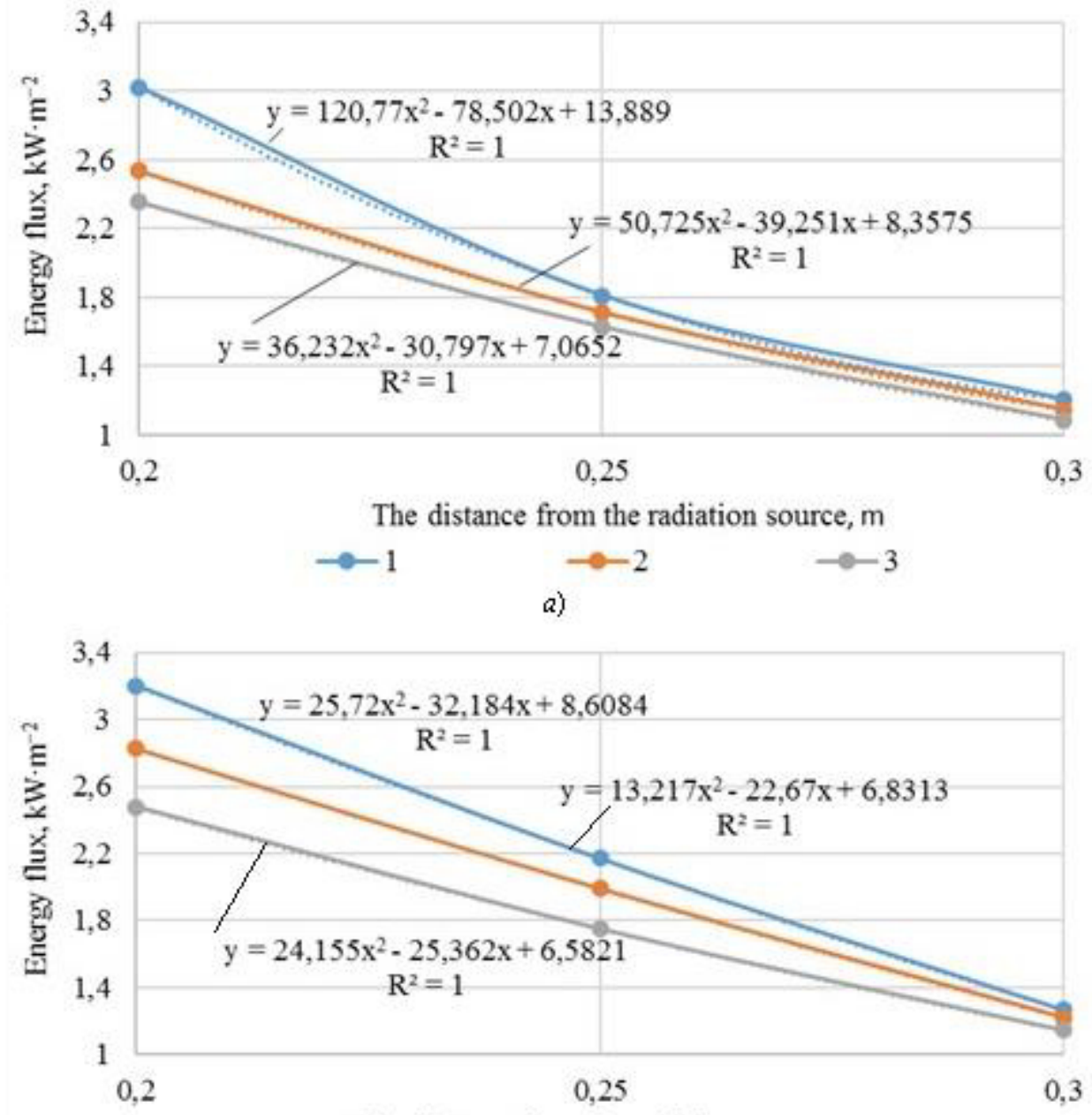

The distance from the radiation source, $m$

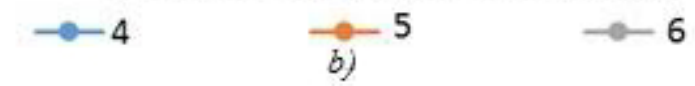

Fig. 2. Dependence of the transmittance of the heat flux from the coating and the distance from the radiation source: for cotton fabric $(a)$ and polyester fabric $(b)$ : 1 - Cotton; 2 - Cotton coated with reflective paint; 3 - Cotton coated with luminous pigments in synthesis paint-and-lacquer coating: 4 Polyester (polyurethane side coated $2000 \mathrm{~mm}$ water column); 5 - Polyester coated with reflective paint; 6 - Polyester coated with luminous pigments in synthesis paint-and-lacquer coating.

where $D$ is rational $E$ quantity of camping localizations in the examined destination $M^{T}$ taking into account the comfort and fire safety, $l=1 \ldots E, t_{l}$ are the coordinates of $l$ the rational point of camping localization in the selected space region, $A_{l}$ are attractions for $l$ rational point of camping localization, $B_{l}$ is evaluation of fire safety for $l$ rational point of camping localization, $K_{l}$ is the assessment of comfortable localization and functioning for $l$ rational point of camping localization.

Assessment of the quality of stay at a particular camping site is formed on the basis of an expert assessment from the implementation of necessary conditions for comfortable stay 
not only in camping, but transport accessibility of the attractions of the destination, noise pollution of camping sites, the link existence etc.

During the research of fire risk at the campsite for buildings and mobile homes we calculated the time of fire effects under different scenarios and the schemes and time of the evacuation. To ensure evacuation safety it is necessary to provide spare escape routes, highlighting in the night time, to remove all explosive and flammable objects from the living quarters, and recreational areas, as well as to divide the territory into separate functional areas.

We propose the method of expert evaluation to determine the level of fire risk in the camping. This method can be used for pre-project researches and preparation for the camping licensing. A survey of experts is carried out using diagnostic papers 1 and 2 and the subsequent assessment of the reliability of the examination on the value of the concordance coefficient and Pearson's chi-squared test. The fire risk $R_{i}$ assessment is defined according to the matrix of consequences $D_{i}$ and probabilities $H_{i}$ :

$$
\mathrm{R}_{\mathrm{i}}\left[\mathrm{H}_{\mathrm{i}}, \mathrm{D}_{\mathrm{i}}\right]=\left\{\begin{array}{l}
0 \text { nрu } k_{i}=0 ; \\
1 \text { nрu } H_{i} \times D_{i}=\{1 \times 1 ; 1 \times 2 ; 2 \times 1 ; 2 \times 2 ; 3 \times 1\} ; \\
2 \text { nрu } H_{i} \times D_{i}=\{1 \times 3 ; 2 \times 3 ; 3 \times 2 ; 4 \times 1\} ; \\
3 \text { nри } H_{i} \times D_{i}=\{1 \times 4 ; 1 \times 5 ; 2 \times 4 ; 3 \times 2 ; 4 \times 2 ; 4 \times 3 ; 5 \times 1\} ; \\
4 \text { nрu } H_{i} \times D_{i}=\{2 \times 5 ; 3 \times 4 ; 3 \times 5 ; 4 \times 4 ; 4 \times 5 ; 5 \times 3 ; 5 \times 4 ; 5 \times 5\}
\end{array}\right.
$$

where $k_{i}=0$ - no threat fire.

The decision on the territory zoning of the camping is carried out using the percolation model, when the whole territory is represented by a grid with nodes (camping objects), and the development and spread of fire is assessed with the possibility of fire spreading from one object to another.

The guidance and techniques for assurance of quality and localization security, position of building structures in the form of campsites, which will create conditions for safe and comfortable domestic and foreign tourists' stay, were designed on the basis of the analysis and evaluation of characteristic features of fire protection system for campsites construction and its components of subsystems.

\section{Conclusion}

To prevent ignition of the tent it is recommended to treat its materials with luminous paint, and not only the tent fabric, but its bracing wires and tent-pegs. Applying reflective and luminous paint on the tent fabric allows escaping of the automobile accident and hooking the tourist for the bracing wires and the pegs in the dark. Also during the evacuation of the campsite in the dark time they apply luminous paint arrows and lines for evacuation routes on the tents, roads and buildings.

Selecting a site for the camping construction it is primarily necessary to install a set of proposals for possible localizations for camping sites, which will allow the tourist to realize their primary motivation, and also to ensure fire safety.

\section{References}

1. Almeida M., Barata J., Viegas D. X., The 7th International Conference on Forest Fire Research, Portugal, 1-12. (2014) DOI: 10.14195/978-989-26-0884-6_72

2. Cherepanov D.A., Ermakov A.S., Servis v Rossii i za rubezhom (Service in Russia and abroad), 1, pp. 204-210. (2014) (In Russ) DOI: 10.12737/2564 
3. Cherepanov D.A., Ermakov A.S., «Pozharovzryvobezopasnost» («Fire and Explosion Safety»), 7, 48-57. (In Russ) DOI: 10.18322/PVB.2016.25.07.48-57. (2016)

4. Cherepanov D.A., Ermakov A.S., Servis v Rossii $i$ za rubezhom (Service in Russia and abroad), vol. 10, no. 2 (63), pp. 141-150. DOI:10.12737/19728 (2016)

5. Ermakov A.S., Cherepanov D.A., Servis v Rossii i za rubezhom (Service in Russia and abroad), vol. 8, no. 7 (54). (In Russ) DOI: 10.12737/7479, (2014)

6. Ermakov A.S., Kokhreidze M.V., Cherepanov D.A., Materialy konferentsii Instituta fizicheskoi kul'tury, sporta i turizma Petrozavod-skogo gosudarstvennogo universiteta (Proceedings of the Conference of the Institute of physical culture, sports and tourism of Petrozavodsk state University), Petrozavodsk, 389-396. (In Russ) (2015)

7. Ermakov A.S., Kokhreidze M.V., Cherepanov D.A., Sovremennye problemy servisa $i$ turizma (Service \& Tourism: Current Challenges), 9(3), 69-75. (In Russ), (2015)

8. Ermakov A.S., Korneev A.A., Cherepanov D.A., Servis plus (Service plus), 8(2), 6570. (In Russ) DOI: 10.12737/3895 (2014)

9. Korolchenko D.A., Sharovarnikov A.F. Advanced Materials Research. 10701072, 1794-1798 (2015)

10. Korolchenko D., Tusnin A., Trushina S., Korolchenko A. International Journal of Applied Engineering Research. 10( 21), 42541-42548. (2015)

11. Orlov G.G., Korolchenko D.A., Fire and Explosion Safety, 24(5), 62-67 (2015)

12. Sakharchuk E.S., Ermakov A.S., Korneev A.A., Cherepanov D.A., Sostoyanie $i$ perspektivy razvitiya avtoturizma $v$ Rossiiskoi Federatsii (RSUTS, Moscow, 2014)

13. Zhang Y., Analysis on Comprehensive Risk Assessment for Urban Fire: Procedia Engineering, 52, pp. 618-623. DOI: 10.1016/j.proeng.2013.02.195 (2013) 